\title{
SIMATIC PLC REGULATION SYSTEM CONTROLLED BY IOT DEVICE
}

\section{E. Machyniak, T. Vince}

Technical University of Košice

Letná, 9, Košice, 042 00, Slovak Republic. E-mail: tibor.vince@ @uke.sk, emil.machyniak@ student.tuke.sk

Purpose. Development experimental sample of IoT (Internet of Things) device to monitor operation of PLC-controlled electric drive system. Originality. The paper deals with the research on surveys for development technical solutions for implementation the IIoT ideas (Industry Internet of Things) using industrial equipment both for managing technological process and for its monitoring using remote Internet-connected device. Methodology. The paper proposes one of the possibilities for development IIoT system with main technological process controlled by industrial PLC and equipped with human-machine interface which provide possibility of remote control using private and public networks. Authors described whole development process starting from device design, prototyping, development, and finishing with software development and testing and also experimental verification of derived results. Results. In this paper it was introduced design and realization of IoT device usable for remote control of PLC regulation system. Device equipped both with classic HMI interface and Web-interface for remote control and monitoring. All developed solutions could be used for purposes of demonstration and teaching IIoT solution. It is possible to look at this IoT device like an alternative to the traditional PLC control using computers and operator panels. Practical value. As result, it is developed two induction motor control system with possibility to monitor and control its operation both using classic HMI and remote control via Web-interface. References 16, figures 10.

Key words: Internet of Things, Human Machine Interface, Web-interface, Programmable Logical Controller, Remote Control.

\section{ПЛК-БАЗОВАНА СИСТЕМА РЕГУЛЮВАННЯ 3 КЕРУВАННЯМ НА ОСНОВІ ІОТ ПРИСТРОЮ}

\section{Е. Мачиняк, Т. Вінсе}

Технічний університет Кошице

вул. Лєтня, 9, м. Кошице, 04200, Словаччина. E-mail: tibor.vince@ tuke.sk, emil.machyniak@ @tudent.tuke.sk

Метою роботи $\epsilon$ розробка експериментального зразка ІоТ (інтернет речей) пристрою для моніторингу i керування роботою системи керування електроприводу на основі ПЛК. У статті наведено результати дослідження підходів щодо розробки технічних рішень для впровадження ідей ІІоТ (промисловий інтернет речей) $з$ використанням промислового обладнання як для керування технологічним процесом, так $\mathrm{i}$ для його моніторингу з використанням пристрою, під’єднаного до мережі Інтернет. Запропоновано одну з можливостей розробки ІІоТ системи з основним контролем технологічного процесу за допомогою промислового ПЛК та обладнаного людино-машинним інтерфейсом, що надає можливість віддаленого керування з використанням приватних та публічних мереж. В роботі описано увесь процес розробки, починаючи з проектування пристрою, розробки прототипу та експериментального зразка, та закінчуючи розробкою програмного забезпечення, тестування та експериментальної перевірки отриманих результатів. У даній статті представлено проектування та створення IоT пристрою, що може використовуватися для віддаленого керування та моніторингу технологічного процесу. Усі розроблені рішення можуть бути використані для задач демонстрації можливостей та навчання при розробці рішень щодо ІІоТ. На розроблений пристрій можна поглянути як на альтернативу традиційним системам керування на основі ПЛК з використанням комп’ютерів та панелей керування. Як результат, було розроблено систему керування двома асинхронними двигунами 3 можливістю моніторингу і віддаленого керування iї роботи як з використанням класичного людино-машинного інтерфейсу, так i віддаленого керування за допомогою веб-інтерфейсу.

Ключові слова: інтернет речей, людино-машинний інтерфейс, веб-інтерфейс, програмований логічний контролер, віддалене керування.

PROBLEM STATEMENT. We are currently standing on the threshold of the fourth industrial revolution, labeled as Industry 4.0 [1] The basic unit of Industry 4.0 is IoT (Internet of Things). The usage of IoT in industry is labeled as IIoT (Industrial Internet of Things). The IIoT will make it possible to extract large amounts of data from industrial processes. These data are labeled as Big Data [2]. Analysis of acquired data will enable industrial enterprises to optimize and streamline production. These changes are an answer to an increasingly unstable market where the product lifecycle is becoming increasingly short. It can be said that the IIoT opens the door for completely new ways of monitoring and controlling production processes [3].

Since the IoT connects individual parts of industry into the large network, one of its possible uses is its connection with the basic unit in automation at present a programmable logic controller (PLC). Department of Theoretical and Industrial Electrical Engineering owns a PLC regulation system. However, this system is a model that can also be applied in industry. The whole system can be regulated by visualization. The compact IoT model can therefore be an innovative alternative to this type of control.

However, the communication between the PLC and the IoT can be quite complicated. One of the reasons 
why this is so is the fact that the IoT sector is starting to develop more strongly only now.

There is a plenty of manufacturers of IoT devices, and so far there is no unification in the used communication protocols. Functioning and trouble free communication between the PLC and the IoT device therefore appears to be essential and key.

EXPERIMENTAL PART AND RESULTS OBTAINED.

\section{ESP8266}

The ESP8266 delivers highly integrated Wi-Fi SoC solution for efficient power usage, compact design and reliable performance in the Internet of Things industry. With the complete and self-contained Wi-Fi networking capabilities, ESP8266EX can perform either as a standalone application or as the slave to a host MCU (MicroController Unit). Besides the Wi-Fi functionalities, ESP8266EX also integrates an enhanced version of Tensilica's L106 Diamond series 32-bit processor and on-chip SRAM [10]. Default $80 \mathrm{MHz}$ CPU clock can be overclocked up to $160 \mathrm{MHz}$ [11].

There are different vendors of board modules based around the ESP8266 chip like Espressif Systems, AiThinker and DOIT. Different modules vary in dimension, flash memory size, number of pins, antenna type etc [12].

For developers was created DevKit NodeMCU as a developer board in 2014. It is open-source platform integrating ESP8266 and USB-TTL bridge via CP1202 or $\mathrm{CH} 340$. One of the main advantages of NodeMCU is SIL header connection where ESP itself is SMD only. Another modification is for instance extended measurable analogue signal voltage from $0-1.0 \mathrm{~V}$ up to 0-3.3 V [13]. ESP chip and developer board NodeMCU is shown on Figure 1.

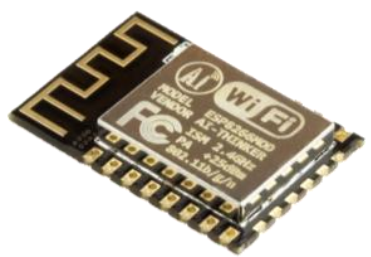

ESP8266

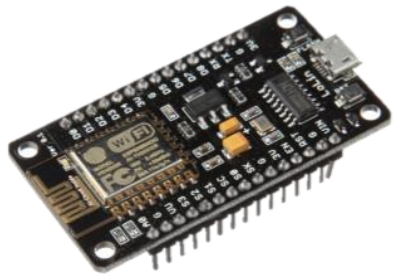

NodeMCU ESP8266

Figure 1 - ESP8266 and NodeMCU

For the centralized access control project was used NodeMCU ESP8266 v1.0 with ESP8266-12E version so below features of the selected models are described.

The ESP8266-12E is mounted with an $4 \mathrm{MB}$ external SPI flash to store user programs. To the key features of the ESP8266 belong support of $802.11 \mathrm{~b} / \mathrm{g} / \mathrm{n}$ (HT20) protocols and STA/AP/STA+AP operation modes with WPA/WPA2 protocol access possibility and WEP/TKIP/AES Encryption supported. There are SDIO $2.0, \quad(\mathrm{H})$ SPI, UART, I2C, I2S and IRDA communication interfaces are integrated. One 10-bit precision SAR ADC and 17 GPIO are also integrated. Mostly each of the GPIO can be configured with internal pull-up, input available for sampling by a software register, input triggering an edge or level CPU interrupt, input triggering a level wakeup interrupt, open-drain or push-pull output driver, or output source from a software register, or a 10-bit sigma-delta PWM [11].

Even the ESP8266-12E has officially 17 GPIO, only 11 of them we can really use [11]. Rests of them are used by NodeMCU or have effect on boot mode.

The NodeMCU could be programmed in Lua language, or in Wiring language used by Arduino in well-known Arduino IDE.

First versions of ESP8266 were used as a slave MCU using only to create WiFi connectivity for master MCU using UART and AT commands. Now ESP8266$12 \mathrm{E}$ exceeds for example common Arduino MEGA 2560 in many parameters for instance CPU clock, memory size for user program, connectivity, ADC resolution etc. It increased area of projects where ESP as an only MCU could be used.

Analysis of user requirements

The following part of the paper is focused on determination of user requirements for PLC regulation system by IoT device.

Control options - It is appropriate that the proposed system could be controlled by several ways. One method should be directly using the designed control device. Such a method can be called local. The control device should have a suitable form of HMI. The control device should have a suitable form of HMI. The secondary way of controlling should provide an alternative to the first described method.

Compactness - It is good to secure suitable form of IoT device. The hardware part of the IoT device should not occupy much space and its design should be suitable for industrial applications.

Compatibility - All components of the proposed system must be compatible to ensure trouble-free communication. These components should support the same communication protocols.

Simplicity and clarity - Processed and monitored data should be displayed appropriately. Therefore screen should have a suitable concept with data appropriately sorted into groups, for instance by motor number. On most important information (speed, torque, temperature and current) should be given the greatest emphasis.

Robustness of the system - The main program should be suitably adjusted to avoid frequent failures or other not defined conditions.

Security -Proposed system should have feature to turn off the entire system at any time, for instance in case of very high values some of the monitored quantities.

\section{System proposal}

Microcontroller - The most important HW part is of course a microcontroller. The big advantage of ESP microcontrollers is their "all in one" feature - they combine microcontroller functions with integrated $\mathrm{Wi}-$ Fi communication interface. Thanks to this feature, two development boards based on ESP8266 or the new 
ESP-32 were considered. Despite the many similarities with the ESP8266 chip, a more powerful development platform based on ESP-32 does not support a number of external libraries usable to make easier easy mutual communication between the devices [4]. Thanks to this fact and advantages described above, the NODEMCU v1.0 V2 development board was chosen as the microcontroller. A detailed description of the development board NodeMCU is in [5].

Touch display -Local way of controlling should have appropriate HMI. The choice fell on Nextion touch displays. The advantages of these displays are their favorable price and benefits of its own integrated microcontroller. This microcontroller will take care about load associated with the graphical interface. Specifically, model NX4832K035 was selected. A detailed description of the model is provided on the manufacturer's website [6].

Development environments - Development environments generally serve to create a program in a particular language. Totally, three development environments were used. A well-known Arduino IDE was selected to create main control program. The second used development environment is the Nextion Editor. In this graphics editor Nextion touch displays can be programmed. The editor is freely available on the manufacturer's site [7]. Third used development environment is Simatic Manager. With the integrated tools of this environment, it is possible to program Siemens PLC. In this case it is primarily about making data from PLC data blocks available. These data blocks contain addresses on which data like motor speed, absolute current or motor temperature are stored.
External libraries - Communication between some parts of the system can sometimes be quite complicated. However, some libraries were created for programmers to making this communication easier. Arduino IDE already contains many of these libraries. All the other necessary libraries must be uploaded into this environment. There are already developed multiple libraries supporting communication Simatic PLC for different platforms [8]:

- 7SNAP - C/C++, Pascal, Phyton, Node.js, .NET/Mono(C\#VB.NET)

- \#7Sharp - Snap7 core in C\#, compatible with Universal Windows Platform, Mono (Win/Linux) and also Win10 IoT for Raspberry

- 7MOKA - Snap7 core in pure Java, Compatible with all Java supported platforms: Windows, Linux, Solaris and Android

- S7 Settimino - Snap7 core in Arduino C, compatible with Arduino UNO R3, Arduino MEGA 2560 R3, but also ESP8266 family and all ESP32 family.

For the proposed system is especially important library Settimino. The purpose of Settimino library is make communication between ESP and PLC easier. Settimino is an open source Ethernet library for interfacing ARDUINOTM / ESP8266 NodeMCU / ESP32 natively with Siemens S7TM PLCs. The library supports communication with older Simatic S7-300 and S7-400 but also newer CPUs: 1200/1500 LOGO 0BA7 and S7200. Library Settimino is freely available on the manufacturer's website [8].

The complete proposal of the system with the described elements is illustrated on Figure 2.

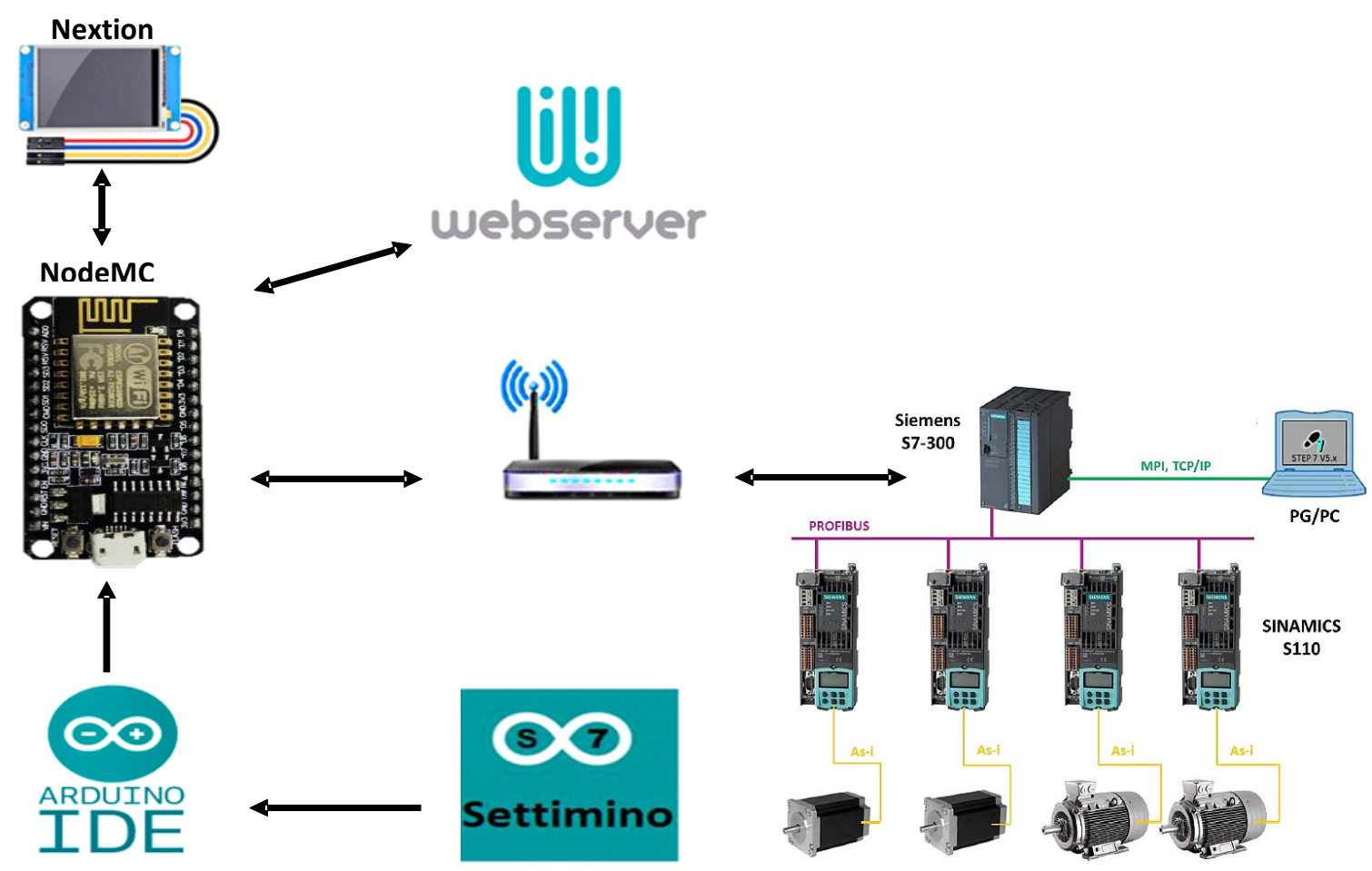

Figure 2 - System proposal 


\section{Realization of IoT device}

The result of the project is a relatively small device with dimensions $13.2 \times 9.8 \times 3 \mathrm{~cm}-$ Figure 6 . Behind the display, on the side of the device there is a button to restart the IoT device. In front there is a Micro USB port used to communicate with the control MCU and also to power the IoT device with a voltage of $5 \mathrm{~V}$. The scheme of control circuit of the IoT device is shown on figure Figure 3 .

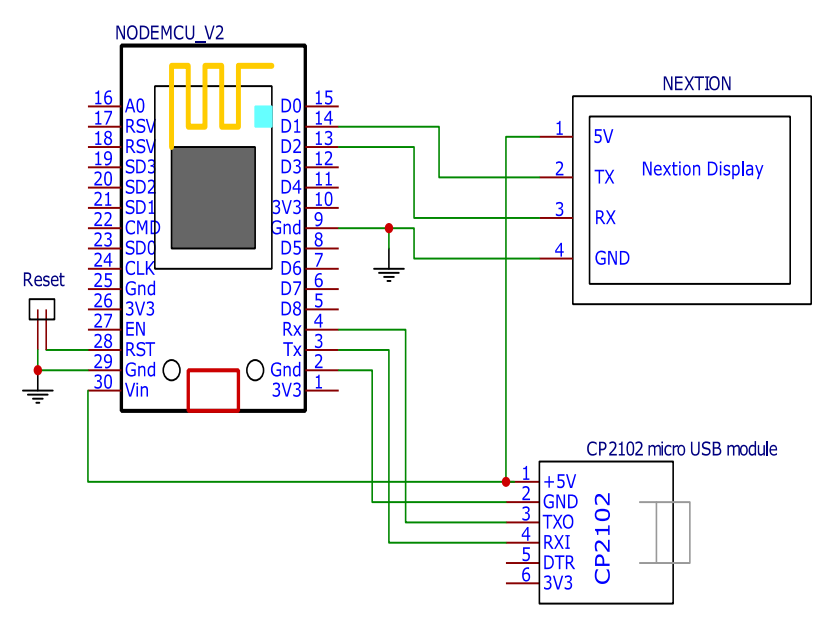

Figure 3 - Scheme of the IoT device control circuit

The main components of the IoT device are: NodeMCU development board, Nextion touch screen and Micro USB module. Inside of the IoT device is control circuit.

According to the scheme were PCB template created. PCB template and template with component position are shown in Figure 4.

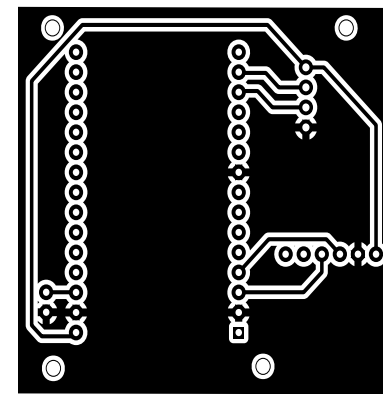

a)

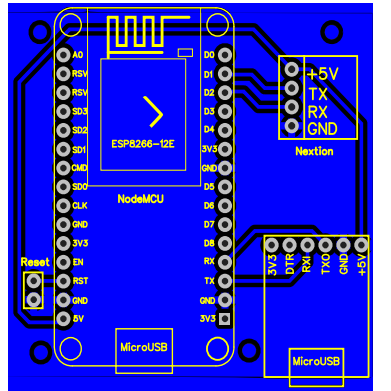

b)
Figure 4 - a) PCB template; b) PCB component position

The individual components of the IoT device are connected by a printed circuit board (PCB). The position of the individual elements on the printed circuit board is shown on Figure 4,b. Mounted PCB is displayed on Figure 5.

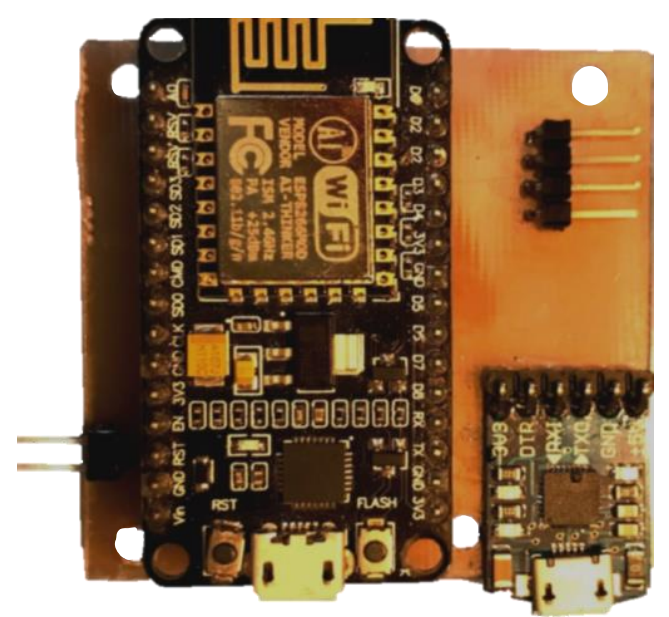

Figure 5 - Placing elements on a real printed circuit board

The control microcontroller is connected to the printed circuit board by a socket into which the control microcontroller is locked. The final form of the IoT device is shown on Figure 6.

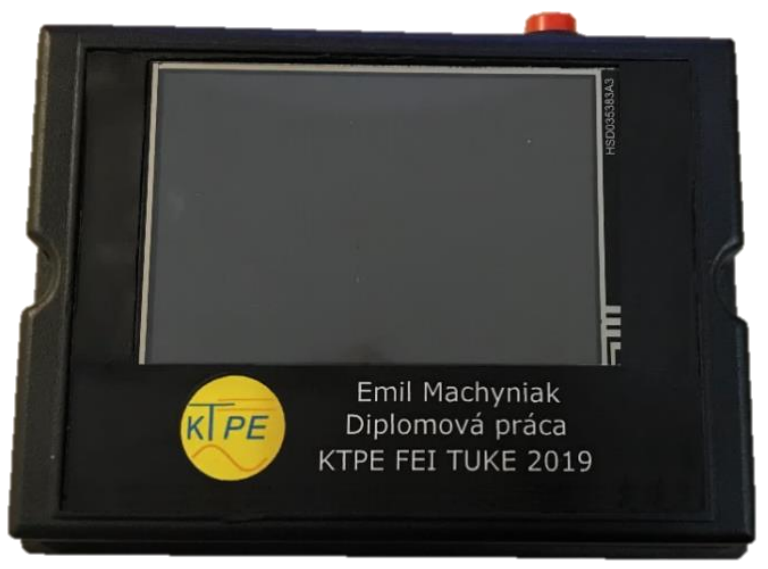

Figure 6 - Final form of IoT device

\section{Local HMI control}

The local control is via a built-in touch screen that can be understood as an HMI. Overall, the IoT device contains three screens. Initial, which is displayed automatically when the IoT device is switched on (Figure 7) and two control screens (Fig. 8) - each for motor1 and motor2.

After successful connection of the IoT device to the Wi-Fi network, the URL address on which the web server runs is displayed on the start screen (Figure 7-1). On this screen it is also possible to set access to system control via the web server using the checkbox (Figure 7-2). The strength, quality of the received $\mathrm{Wi}-\mathrm{Fi}$ signal (Figure 7-3) is also shown on the initial screen. Using buttons Motor 1 or Motor 2 (Figure 7-4) Controlling screen (Figure 8) is activated. 


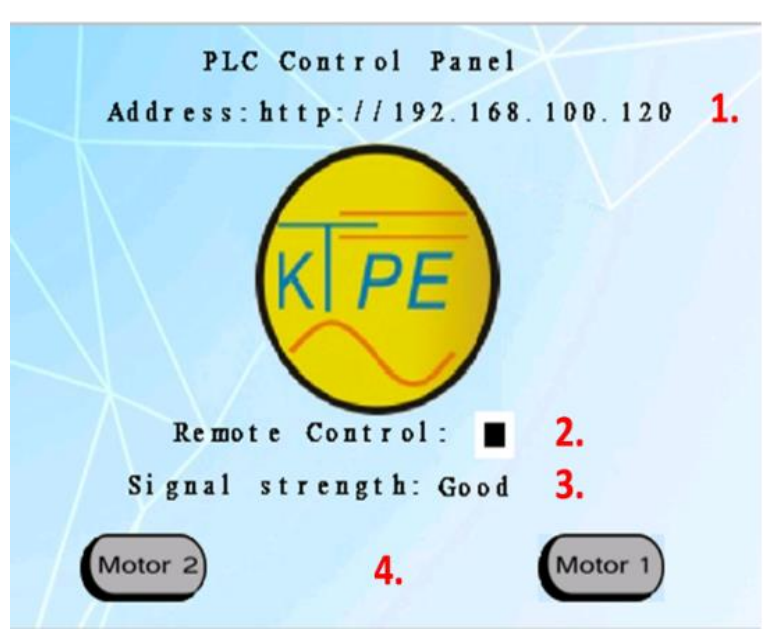

Figure 7 - HMI initial screen

Monitored variables for which the screens provide information are:

- Real rpm [revolutions per minute];

- Set rpm [revolutions per minute];

- Temperature inside the motor $\left[{ }^{\circ} \mathrm{C}\right]$;

- Absolute current value [mA];

- Torque $[\mathrm{mN} / \mathrm{m}]$.

These data are cyclically updated approximately every 7 seconds. Touch-sensitive active elements buttons (Figure 8-8) and slider (Figure 8-9) are located on the controlling screens. On the right side of these screens are the directional buttons "Back" (Figure 8-7), which allows to get back to the home screen as well as the engine on / off button (Figure 8-5). The bottom of the screen is made up of active elements used to set the desired speed. You can use either the slider or one of the "-10 rpm", "0 rpm" and "+10 rpm" buttons to set them. The buttons "-10 rpm" and "+10 rpm" are similar in meaning. By pressing them, it is possible to adjust the currently set motor speed slightly (on the tenth level). The task of the buttons is to add (button "+10 rpm") or to decrease (button "-10 rpm") the current value of the set rpmr and then round the new value to the level of tens (nearest tens). For instance, if the current set rpm value is $1653 \mathrm{rpm}$, pressing the "+10 rpm" button causes the change to $1660 \mathrm{rpm}$. The " $0 \mathrm{rpm}$ " button is used to set the zero speed. After pushed any buttons which is for setting rpm, slider value is updated. The desired set rpm value can be set within the range of $\langle-3000$; 3000〉, where negative values indicate a counter clockwise rotation. Approximately in the middle of the screen is a red inscription "Updating" (Fig. 8-6.) It signals the updating of the monitored variables. During this cycle, all screen elements are inactive to touch.

\section{Remote WEB control}

Controlling via web server does not offer such a quick response and is slower compared to HMI. Its performance is determined by several factors like Wi-Fi signal strength, delay caused by communication with PLC etc. so it is recommended to use web interface as a secondary way of control.

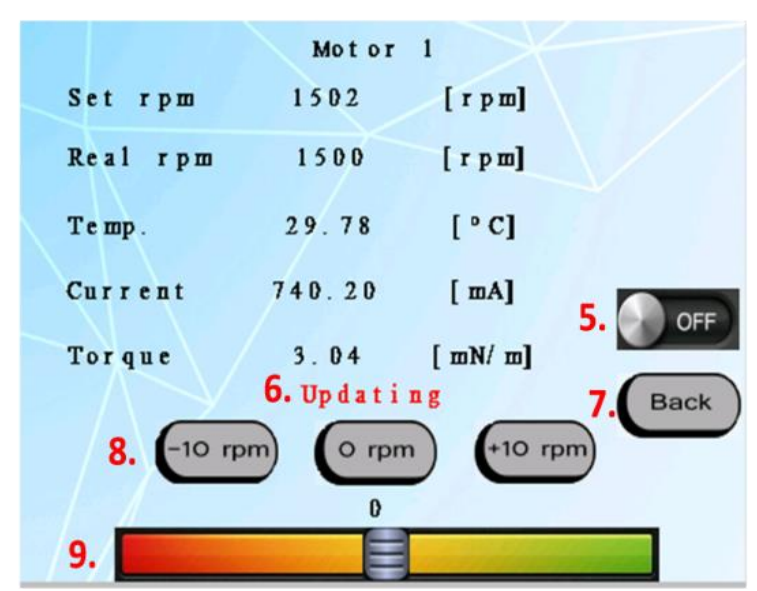

Figure 8 - Controlling screen

URL address of the IoT device is displayed on HMI initial screen (Figure 7). On initial screen is also remote control option, where controlling via web site is enabled or disabled. Displayed web page depend on this option. If the remote control option is disabled, only read-only data are displayed. Otherwise, also control components are displayed and the user can control the drives.

Web user interface with disabled control is shown in Figure 9. On the web page are following information component:

- State (of the Simatic frequency converter), could contain value Active or Inactive; PLC;

- Set rpm contains information about rpm set in

- Real rpm shows real motor speed read by PLC;

- Temperature, Current and Torque.

Web user interface with enabled control is shown in Figure 10. Compared to the previous option, new additional control components are displayed:

- State control, where user is able to activate or deactivate Simatic converter

- Control set rpm for specific motor, where at one time only one motor is possible to change parameters. Similarto local control, when using the web server, it is possible to set the set rpm value within the interval $<-3000,3000>$.

CONCLUSIONS. The technologies used in industrial automation are constantly improving. That is why we are not yet able to say exactly how enterprises of the future will look like. However, we know that Industry 4.0 intends to create decentralized enterprises, which will themselves decide and control the enterprise. The basic element that enables them to do so is the IoT and its implantation into the industry labeled as IIoT. IIoT opens the door to completely new forms of monitoring and regulating production processes.

In this paper was introduced design and realization of IoT device usable for remote control of PLC regulation system. It is possible to look at this IoT device like an alternative to the traditional PLC control using computers and operator panels. 


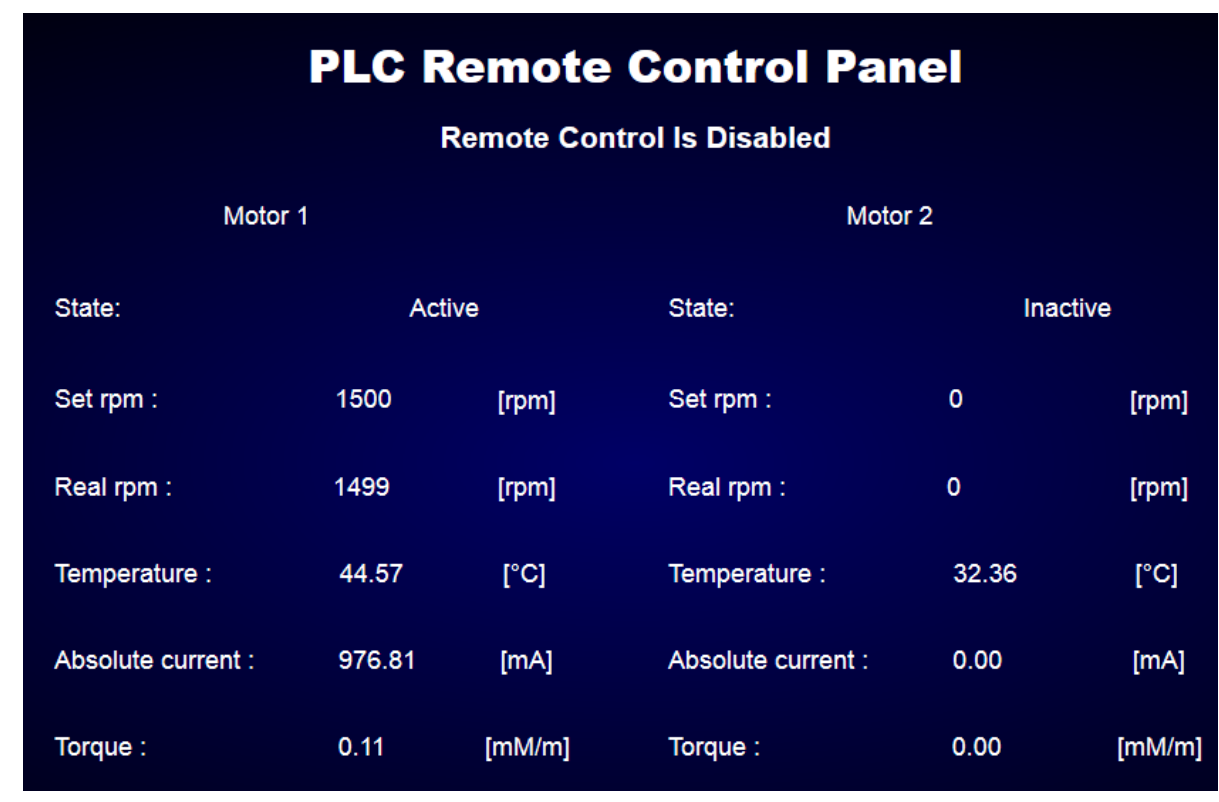

Figure 9 - Control web page, remote control disabled

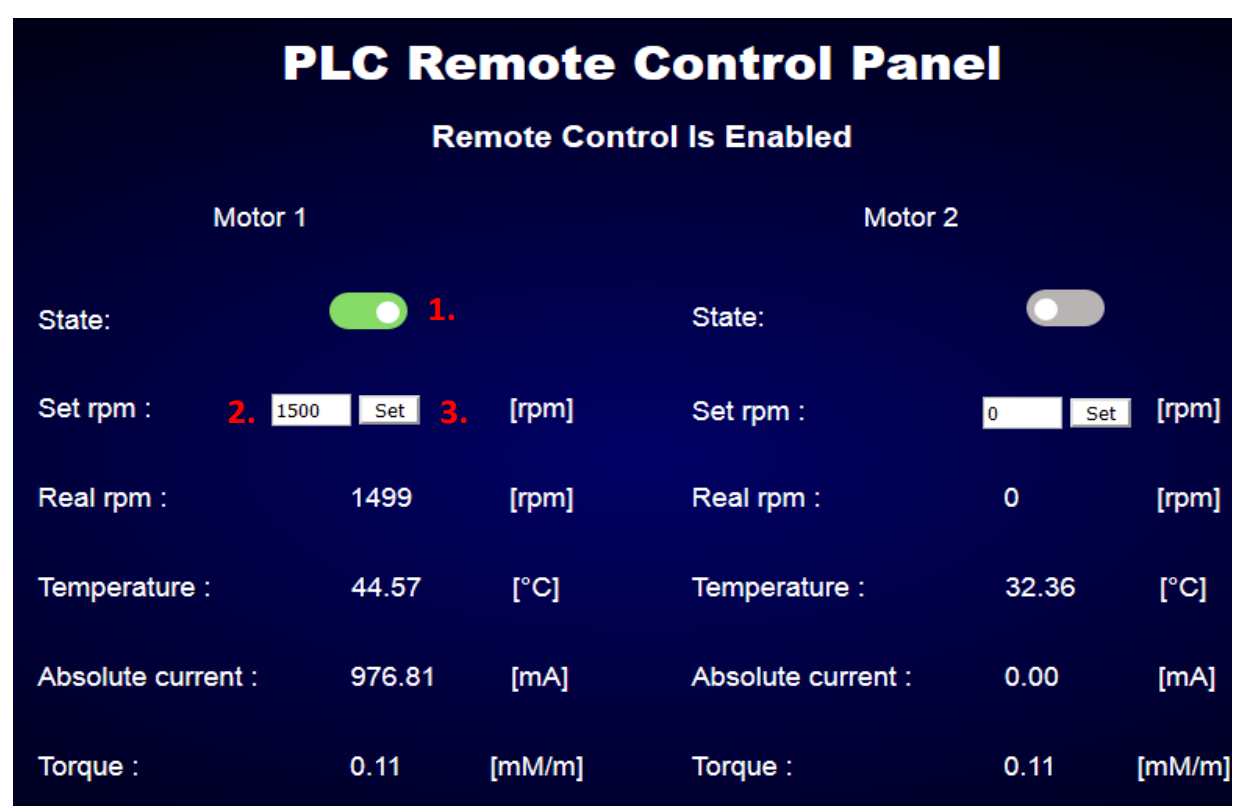

Figure 10 - Control web page, remote control enabled

\section{ACKNOWLEDGEMENT.}

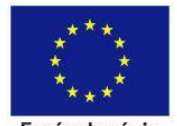

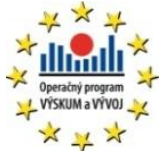

We support research activities in Slovakia / Project is co-financed

from EU funds. This paper was developed within the Project "Centre of Excellence of the Integrated Research \& Exploitation the Advanced Materials and Technologies in the Automotive Electronics ", ITMS 26220120055

\section{REFERENCES}

1. Ješko, V. (2016). Štvrtá priemyselná revolúcia. In Quark : magazín o vede a technike, 22, 12. Retrieved from http://www.quark.sk/tovarne-buducnosti/

2. GE Digital: Everything you need to know about the Industrial Internet of Things. Retrieved from https://www.ge.com/digital/blog/everything-you-needknow-about-industrial-internet-things

3. i-SCOOP: Industry 4.0: the fourth industrial revolution - guide to Industrie 4.0. Retrieved from https://www.i-scoop.eu/industry-4-

0/\#In_the_end_its_the_human_system_that_ddecide

4. Espressif: ESP32 Technical Reference Manual. Retrieved from https://www.espressif.com/sites/default/ files/documentation/esp32_datasheet_en.pdf 
5. Koyanagi, F. NodeMCU ESP8266: Details and Pinout. Retrieved from https://www.instructables.com /id/NodeMCU-ESP8266-Details-and-Pinout/

6. Nextion: NX4832K035, Datasheet. Retrieved from https://nextion.tech/datasheets/nx4832k035/

7. Nextion: Nextion Editor. Retrieved from https://nextion.tech/nextion-editor-ver-0-58/

8. Nardella, D. Step7 Open Source Ethernet Communication Suite. Retrieved from http://snap7.sourceforge.net/

9. Nardella, D. ARDUINO ${ }^{\text {TM }}$ Ethernet communication library. Retrieved from http://settimino.sourceforge.net/

10. Esprif: ESP8266 Technical Reference. https://www.espressif.com/sites/default/files/documentatio n/esp8266-technical_reference_en.pdf

11. Kováč, D., Kováčová, I., \& Molnár, J. (2009). Elektromagnetic compatibility - measurement. Košice: Published by TU FEI. ISBN 978-80-553-0151-8

12. Guzan, M., Špaldonová, D., Hodulíková, A.,
Tomčíková, I., \& Gladyr, A. (2011). Boundary Surface and Load Plane of the Ternary Memory. Electromechanical and energy saving systems, 15, 3, 163-167.

13. Rahadian, Helmy, Waluyo Nugroho, \& Dwi Nurul Izzhati (2016). Siemens CPU1215C input expansion and remote monitoring with Arduino bridge. 2016 6th International Annual Engineering Seminar (InAES). IEEE.

14. Dziak, J., \& Tomčíková, I. (2016). Models of ideal linear elements of DC and AC circuits and circuit simulation in MATLAB using Sparse Tableau analysis. SSIEE 2016, 5, 139-141.

15. Nicholson, Andrew, Helge Janicke, \& Antonio, Cau (2014). Position Paper: Safety and Security Monitoring in ICS/SCADA Systems. ICS-CSR.

16. Medved, Blaž. (2014). Vodenje modelov Lego Mindstorms NXT z industrijskimi krmilniki Siemens. Diss. Univerza $v$ Ljubljani.

\section{ПЛК-ОСНОВАННАЯ СИСТЕМА РЕГУЛИРОВАНИЯ С УПРАВЛЕНИЕМ НА ОСНОВЕ ІОТ УСТРОЙСТВА}

\section{Е. Мачиняк, Т. Винсе}

Технический университет Кошице

ул. Летна, 9, г. Кошице, 04200, Словакия. E-mail: tibor.vince@tuke.sk, emil.machyniak@student.tuke.sk

Целью работы является разработка экспериментального образца ІоТ (интернет вещей) устройства для мониторинга и управления работой системы управления электропривода на основе ПЛК. В статье приведены результаты исследования подходов по разработке технических решений для внедрения идей IIоT (промышленный интернет вещей) с использованием промышленного оборудования как для управления технологическим процессом, так и для его мониторинга с использованием устройства, подключенного к сети Интернет. Предложено одну из возможностей разработки IIоT системы с основным контролем технологического процесса с помощью промышленного ПЛК и оборудованного человеко-машинным интерфейсом, предоставляющей возможность удаленного управления с использованием частных и публичных сетей. В работе описано весь процесс разработки, начиная с проектирования устройства, разработки прототипа и экспериментального образца, и заканчивая разработкой программного обеспечения, тестирование и экспериментальной проверки полученных результатов. В данной статье представлено проектирование и создание ІоТ устройства, которое может использоваться для удаленного управления и мониторинга технологического процесса. Все разработанные решения могут быть использованы для задач демонстрации возможностей и обучения при разработке решений по ІІоТ. На разработанное устройство можно посмотреть как на альтернативу традиционным системам управления на основе ПЛК с использованием компьютеров и панелей управления. Как результат, была разработана система управления двумя асинхронными двигателями с возможностью мониторинга и удаленного управления ее работы как с использованием классического человекомашинного интерфейса, так и удаленного управления с помощью веб-интерфейса.

Ключевые слова: интернет вещей, человеко-машинный интерфейс, веб-интерфейс, программируемый логический контроллер, удаленное управление. 